\title{
Role of cysteine in the improvement of Y-aminobutyric acid production by nonproteolytic Levilactobacillus brevis in coculture with Streptococcus thermophilus
}

\author{
Tingting Xiao $(1)$ and Nagendra P. Shah* () \\ Food and Nutritional Science, School of Biological Sciences, University of Hong Kong, Pokfulam Road, 999077 Hong Kong
}

\section{ABSTRACT}

Previous research has showed that nonproteolytic Levilactobacillus brevis 145 (L) in coculture with Streptococcus thermophilus 1275 (S), not Lactobacillus delbrueckii ssp. bulgaricus (Lbu), was able to produce $\gamma$-aminobutyric acid (GABA) during milk fermentation in the presence of monosodium glutamate (MSG). It was assumed that differences of casein hydrolysis patterns between Strep. thermophilus 1275 and L. bulgaricus caused the phenomenon. Moreover, the GABA content was low and residual MSG was high in SLfermented milk. In our research, comparison of peptide profiles determined by liquid chromatography/tandem mass spectrometry showed that $\alpha_{S 2}$-casein, $\beta$-casein, and $\kappa$-casein degradation by L. bulgaricus and Strep. thermophilus varied. Importantly, the peptide number in the L and Lbu coculture group increased compared with the Lbu monoculture group, whereas the peptide number in the SL coculture group decreased in comparison with $\mathrm{S}$ monoculture group, suggesting that L. bulgaricus was not able to provide peptides for the growth of $L b$. brevis 145 . Furthermore, we found that after supplementation with cysteine $(50 \mathrm{mg} / \mathrm{L})$ during milk fermentation by SL, $10 \mathrm{~g} / \mathrm{L}$ MSG was converted into $4.8 \mathrm{~g} / \mathrm{L}$ GABA with a minimum level of residual MSG, viable cell counts of $L b$. brevis and lactic acid production were increased, and the casein hydrolysis pattern was not influenced. Moreover, sulfhydryl group-containing chemicals including cystine, reduced glutathione, and oxidized glutathione showed effects similar to that of cysteine in improving GABA production. Finally, when L. bulgaricus YIB2 was combined with SL, supplementation of cysteine was also able to significantly improve GABA production.

Key words: $\gamma$-aminobutyric acid, cysteine, casein hydrolysis, bacteria coculture

Received October 26, 2021.

Accepted December 27, 2021

*Corresponding author: npshah@hku.hk

\section{INTRODUCTION}

$\gamma$-Aminobutyric acid (GABA), a 4-carbon nonprotein amino acid, is a major inhibitory neurotransmitter in the central nervous system (Bowery and Smart, 2006), and GABA-rich food is of interest for the food industry as it provides various physiological functions, such as a neuroprotective effect ( $\mathrm{Li}$ et al., 2016), attenuation of cardiac apoptosis in spontaneously hypertensive rats (Cherng et al., 2014), and reduction of blood pressure (Hayakawa et al., 2004; Shimada et al., 2009).

High GABA-producing lactic acid bacteria have commonly been applied to produce GABA-rich milk beverages, cheeses, and yogurts for promoting human health, as dairy products can serve as highly effective carriers of GABA (Sun et al., 2009; Song and Yu, 2018). Milk protein is a well-known precursor protein for the generation of peptides degraded by lactic acid bacteria. Development of liquid chromatography/ tandem MS (LC/MS-MS) enables us to determine peptide sequences, peptide counts, and peptide intensities in casein hydrolysates. Miclo et al. (2012) found that numbers and types of peptides released from casein were strain-dependent. Hydrolysis appeared to be linked with the accessibility of different casein regions by protease. For Lactobacillus helveticus, rapid hydrolysis of pure $\beta-\mathrm{CN}$ was observed, and the hydrolysis kinetics of $\alpha_{\mathrm{S}_{1}}-\mathrm{CN}$ varied based on the number of cell envelope proteinases. When only PrtH2 proteinase was present, 22 to $30 \%$ of the peptides originated from $\alpha_{\mathrm{S} 1}$ CN. The percentage increased to 41 to $49 \%$ for strains in which both PrtH2 and PrtH proteinases were expressed (Sadat-Mekmene et al., 2011). For Bifidobacterium longum KACC9156, a total of 28 peptides were generated from the $<3-\mathrm{kDa}$ fraction, corresponding to $11 \mathrm{CN}-\beta, 16 \alpha_{\mathrm{S}^{-}} \mathrm{CN}$, and $1 \kappa-\mathrm{CN}$ peptides. In bovine kefir prepared with kefir grains, 124 peptides were identified, mainly released from $\mathrm{CN}-\beta$, followed by $\alpha_{\mathrm{S}_{1}} \mathrm{CN}$, $\kappa-\mathrm{CN}$, and $\alpha_{\mathrm{S}_{2}} \mathrm{CN}$ (Ebner et al., 2015). A growing body of publications suggest the multifunctional roles of milk-derived peptides, which included antihypertensive (Rai et al., 2017), antioxidative (Pihlanto, 2006; Power 
et al., 2013), and immunoregulation effects (Lahov and Regelson, 1996), and more. These peptides are capable of acting as additives in food manufacturing for the development of functional dairy products with beneficial effects for human health.

Applying high GABA-producing lactic acid bacteria in fermenting GABA-enriched dairy products has been an increasing trend (Cui et al., 2020). Levilactobacillus species, especially Levilactobacillus brevis, have been confirmed as the highest GABA producers isolated from Korean kimchi and other fermented vegetables (Wu and Shah, 2017). It has been documented that $L b$. brevis of plant origin may not be able to survive in milk because of the absence of genes coding extracellular or other wall-anchored proteinases. Wu et al. (2015) reported a novel and promising method for manufacturing GABA-rich fermented milk by coculturing $L b$. brevis 145 and Streptococcus thermophilus 1275 in the presence of monosodium glutamate (MSG). However, in their research, the final GABA concentration was only $0.265 \mathrm{~g} / \mathrm{L}$, and the residual MSG $(1.2 \mathrm{~g} / \mathrm{L})$ supplemented as substrate for GABA production was relatively high, which was reported to promote an undesirable taste (Jinap and Hajeb, 2010). It would be of great economic importance to improve the GABA yield and simultaneously reduce the level of residual MSG in fermented milk. Most milk proteins ( $\alpha$ - and $\beta$-caseins) do not contain cysteine in their amino acid composition (Gordon et al., 1949); cysteine could be an essential amino acid for $L b$. brevis, and this supplementation would enhance growth and consequent GABA production by Lb. brevis. Dave and Shah (1997) also reported that cysteine could improve viability of probiotics in fermented milk by providing essential growth factors and lowering the redox potential. Until now, very little information has been published on the effect of cysteine on improving GABA production by $L b$. brevis during milk fermentation.

In our research, we aim to find (1) the contribution of specific casein hydrolysis pattern by Strep. thermophilus 1275 and Lactobacillus bulgaricus coculture (SL) to the growth of $L b$. brevis during milk fermentation; (2) ways to increase GABA content and reduce the amount of MSG in SL-fermented milk; (3) the effects of coculture and cysteine on casein hydrolysis; and (4) whether the mixture of $L$. bulgaricus and SL are capable of producing GABA-enriched milk in the presence of cysteine. The successful resolution of these issues would lay a foundation for the development of functional dairy products.

\section{MATERIALS AND METHODS}

\section{Bacterial Strains and Cultivation Conditions}

Levilactobacillus brevis NPS-QW-145 and 3 different Lactobacillus delbrueckii ssp. bulgaricus strains (Table 1) were activated in Difco lactobacilli de Man, Rogosa, and Sharpe (MRS) broth (Becton, Dickinson and Co.), and Strep. thermophilus strain 1275 was cultivated in M17 broth (Becton, Dickinson and Co.). Working cultures were propagated 3 times consecutively using $1 \%$ inoculation in the previously listed media (MRS or M17) at $37^{\circ} \mathrm{C}$ for $16 \mathrm{~h}$. Cell counts of the working cultures were enumerated on MRS or M17 agar plates using the plate counting method before inoculation in reconstituted skim milk (RSM). The initial cell counts for both L. brevis 145 and Strep. thermophilus were $\sim 1$ $\times 10^{9} \mathrm{cfu} / \mathrm{mL}$.

\section{Parameter Selection and Optimization for GABA-Rich Milk}

For coculture fermentation, Strep. thermophilus 1275 $(1 \%, \mathrm{vol} / \mathrm{vol})$ and $L b$. brevis $145(3 \%, \mathrm{vol} / \mathrm{vol})$ were inoculated together into 10\% (wt/vol) RSM for $48-\mathrm{h}$ fermentation at $37^{\circ} \mathrm{C}$. The one-factor-at-a-time strategy was employed to identify concentration ranges of MSG (1-5 g/L), cysteine (25-200 mg/L), pyridoxal phosphate (PLP; 0.01-0.05 $\mathrm{mM}$ ), and whey protein hydrolysate (WPH; 2-10 g/L) for improving GABA production during milk fermentation. Thereafter, the individual effects of cysteine, PLP, and WPH in the listed concentrations on GABA production in the presence of $1 \mathrm{~g} / \mathrm{L}$ of MSG was examined. Finally, the best combination of MSG (concentration ranging from 0 to $10 \mathrm{~g} / \mathrm{L}$ ) and cysteine (concentrations ranging from 0 to $300 \mathrm{mg} / \mathrm{L}$ ) for improving the GABA production level by $L b$. brevis 145 coculture with Strep. thermophilus 1275 was determined. The conversion ratio of MSG to

Table 1. Starter bacteria strains used for milk fermentation in this study

\begin{tabular}{lll}
\hline Species & Strain ID & Origin \\
\hline Streptococcus thermophilus & ASCC1275 & Australian Starter Culture Research Center \\
Lactobacillus delbrueckii ssp. bulgaricus & ASCC756 & Australian Starter Culture Research Center \\
& ASCC859 & Australian Starter Culture Research Center \\
Levilactobacillus brevis & YIB2 & Commercial yogurt isolate \\
\hline
\end{tabular}


GABA was calculated by the following formula: conversion ratio $(\%)=100 \times[$ Final GABA concentration $(\mathrm{m} M) /$ Initial MSG concentration $(\mathrm{m} M)]$.

\section{Effect of Sulfur-Containing Chemicals on GABA Improvement}

Sulfur-containing chemicals, including cystine, methionine, reduced glutathione, and oxidized glutathione, were individually supplemented at $50 \mathrm{mg} / \mathrm{L}$ for milk fermentation at $37^{\circ} \mathrm{C}$ with coculture of Strep. thermophilus 1275 and Lb. brevis 145 in the presence of $2 \mathrm{~g} / \mathrm{L}$ MSG, after 48-h fermentation, and GABA production was determined by reversed-phase HPLC, as will be discussed.

\section{Sample Preparation from 48-h Milk Fermentation With or Without Cysteine}

Milk fermentation was carried out in $10 \%$ (wt/vol) RSM supplemented with MSG at the level of $2 \mathrm{~g} / \mathrm{L}$. First, an aliquot of $40 \mathrm{~mL}$ of the RSM and MSG mixture was divided into $50-\mathrm{mL}$ sterile centrifuge tubes, and 3\% (vol/vol) Lb. brevis 145 and 1\% (vol/vol) Strep. thermophilus 1275 were inoculated with and without 50 $\mathrm{mg} / \mathrm{L}$ cysteine. After mixing, $3.5 \mathrm{~mL}$ of the inoculated RSM containing MSG, with or without cysteine, was distributed into 5-mL sterile polystyrene round-bottom tubes and incubated statically at $37^{\circ} \mathrm{C}$. Each tube was withdrawn at $0,3,6,9,12,16,20,24,36$, and $48 \mathrm{~h}$ to check bacterial growth, $\mathrm{pH}$ of the fermented milk, GABA and MSG concentrations, lactic acid production, and lactose and galactose utilization.

\section{Determination of GABA and Residual MSG by Reversed-Phase HPLC}

The concentrations of GABA and MSG were measured as previously described with a minor modification (Wu and Shah, 2015). Briefly, Carrez solutions were used to remove milk proteins before reversed-phase HPLC analysis for residual MSG and generated GABA. One milliliter of fermented milk was added into $4.0 \mathrm{~mL}$ of distilled water, followed by addition of $0.25 \mathrm{~mL}$ of Carrez I solution (0.25 $\mathrm{M}$ potassium ferrocyanide) and $0.25 \mathrm{~mL}$ of Carrez solution II (0.50 $M$ zinc acetate). Then, the mixture was thoroughly mixed using a vortex, and kept for $1 \mathrm{~h}$ at $25^{\circ} \mathrm{C}$ until the precipitation of milk proteins, followed by centrifugation at $5,000 \times g$ and $25^{\circ} \mathrm{C}$ for $40 \mathrm{~min}$. Supernatants were collected and filtered through a $0.20-\mu \mathrm{m}$ Millipore filter. Filtrates were then freeze-dried, followed by re-dissolving in 1 $\mathrm{mL}$ of double-distilled water and removing residues by centrifugation at $4^{\circ} \mathrm{C}$ and $5,000 \times g$ for $40 \mathrm{~min}$. Dansyl derivatization of free amino acids including MSG and GABA in the supernatants was carried out, followed by HPLC analysis of dansyl amino acids.

\section{Estimation of Lactose, Glucose, Galactose, and Lactic Acid}

The concentrations of lactose, glucose, and galactose and lactic acid were measured as previously described with a minor modification (Padmanabhan et al., 2018). Utilization of lactose, glucose and galactose, and production of lactic acid were simultaneously quantified from $10 \mu \mathrm{L}$ of sample injected into a Shimadzu model LC-2010A (Shimadzu Corp.) system equipped with HPX-87H anion exchange column $(300 \times 7.8 \mathrm{~mm}, 9$ $\mathrm{mm}$, Bio-Rad Laboratories Inc.). An isocratic elution was performed using $5 \mathrm{mM} \mathrm{H} \mathrm{H}_{2} \mathrm{SO}_{4}$ at a flow rate of 0.6 $\mathrm{mL} / \mathrm{min}$ for $30 \mathrm{~min}$ and column temperature of $65^{\circ} \mathrm{C}$. A refractive index detector and UV-Vis detector $(220$ $\mathrm{nm})$ were connected to simultaneously determine the concentrations of lactose, glucose, galactose, and lactic acid.

\section{Measurement of the $\mathrm{pH}$ of Fermented Milks}

The $\mathrm{pH}$ of the fermented milks was measured using an Orion Model 250A portable $\mathrm{pH}$ meter (Thermo Scientific).

\section{Enumeration of Viable Lb. brevis 145 and Strep. thermophilus 1275 in Fermented Milk}

Samples were taken during milk fermentation as previously described, to enumerate the counts of Strep. thermophilus 1275 and Lb. brevis 145 using selective media as previously described (Wu et al., 2015). The M17 agar plates for Strep. thermophilus were aerobically incubated at $37^{\circ} \mathrm{C}$ for $48 \mathrm{~h}$, and MRS agar plates for enumerating $L b$. brevis 145 were aerobically incubated at $37^{\circ} \mathrm{C}$ for $48 \mathrm{~h}$, followed by counting of colonies.

\section{Peptide Extract}

Milk fermentation applying monoculture of $L$. bulgaricus 859 (8), L. bulgaricus YIB2 (Y), and Strep. thermophilus $1275(\mathbf{S})$, and coculture of Lb. brevis $(\mathbf{L})$ 145 with one of L. bulgaricus 859 (8L), L. bulgaricus YIB2 (YL), and Strep. thermophilus 1275 (SL), as well as cocultures with cysteine (8LC, YLC, SLC), were carried out at $37^{\circ} \mathrm{C}$ for $48 \mathrm{~h}$. An aliquot of $4 \mathrm{~mL}$ of fermented milk in each batch $(8,8 \mathrm{~L}, 8 \mathrm{LC}, \mathrm{Y}, \mathrm{YL}, \mathrm{YLC}$, $\mathrm{S}, \mathrm{SL}$, and SLC) was diluted with an equal amount of deionized water, followed by centrifugation at 5,000 $\times$ $g$ and $4^{\circ} \mathrm{C}$ for 30 min to remove coagulated caseins and 
bacteria. Ultrafiltration centrifugal tube with $10-\mathrm{kDa}$ cutoff (Millipore) was used to ultrafilter the supernatants at $5,000 \times g$ and $20^{\circ} \mathrm{C}$ for $30 \mathrm{~min}$, and ultrafiltrate was loaded onto a $\mathrm{C} 18$ solid-phase extraction column (Waters Corp.) to perform desalting 3 times for each sample. The eluate containing target peptides was freeze-dried to powder.

\section{LC-MS/MS and Data Analysis}

The lyophilized peptide fractions were resuspended in double-distilled water containing $0.1 \%$ formic acid, and an aliquot of $5 \mu \mathrm{L}$ of peptide-containing solvent was loaded into a nanoViper C18 (3- $\mu \mathrm{m}, 100-\AA$, Thermo Scientific) trap column for analysis. The generated RAW files of MS/MS data were converted to MGF by Proteome Discoverer (version 2.1.0.81, Thermo) and were searched against a Bos taurus-reviewed database (6,008 sequences) using Mascot Daemon (version 2.3.2). No enzyme or static modification was set for database searching. Precursor and fragment mass tolerance were set to $10 \mathrm{ppm}$ and $0.05 \mathrm{Da}$, respectively. The obtained peptide sequence data set was visualized and compared with a novel online tool, Peptigram (Manguy et al., 2017), which is implemented as a web application and is freely available for academic use at http://bioware .ucd.ie/peptigram.

\section{Effects of Cysteine on GABA Yield in Mixtures of SL and L. bulgaricus Strains}

Milk fermentation using culture Lb. brevis 145 and different L. bulgaricus strains with or without Strep. thermophilus and with and without cysteine was also carried out. Fermentation was carried out in 10\% (wt/ vol) RSM with $2 \mathrm{~g} / \mathrm{L}$ of MSG at $3 \%$ (vol/vol) Lb. brevis 145 inoculation level. For coculturing of Lb. brevis 145 with $L$. bulgaricus in RSM, the inoculation level of $L b$. brevis 145 was $3 \%$ (vol/vol) and that of L. bulgaricus was $1 \%$ (vol/vol). For the 3-bacteria coculture batch, the inoculation levels of L. bulgaricus and Strep. thermophilus 1275 were each $0.5 \%$ (vol/vol), and that of $L b$. brevis 145 was $3 \%$ (vol/vol). All the fermentation experiments were carried out at 2 occasions under static conditions at $37^{\circ} \mathrm{C}$ for $48 \mathrm{~h}$.

\section{Statistical Analysis}

All data in the bar charts, line charts, and tables are means \pm standard deviation. Significant differences $(P<0.05, P<0.01, P<0.001)$ among the groups were calculated by one-way ANOVA using IBM SPSS Statistics version 20.0.

\section{RESULTS}

\section{Strain-Specific Casein Hydrolysis Patterns of Strep. thermophilus and L. bulgaricus}

Liquid chromatography/tandem MS was performed to investigate the differences of casein hydrolysis patterns between L. bulgaricus and Strep. thermophilus. By comparing the peptide components in L. bulgaricus and Strep. thermophilus single-culture groups (Table 2), it was observed that the total number of the peptide degraded by $L$. bulgaricus was higher than that degraded by Strep. thermophilus. Lactobacillus bulgaricus and Strep. thermophilus showed different preferences to digest $\alpha_{\mathrm{S}^{-}} \mathrm{CN}, \alpha_{\mathrm{S} 2}-\mathrm{CN}, \mathrm{CN}-\beta$, and $\kappa-\mathrm{CN}$. In the Strep. thermophilus 1275 single-culture group, peptides from $\mathrm{CN}-\beta$ and $\alpha_{\mathrm{S}_{1}} \mathrm{CN}$ accounted for $33 \%$, respectively, whereas peptides from $\alpha_{\mathrm{S} 2^{-}} \mathrm{CN}$ and $\kappa-\mathrm{CN}$ accounted for 12 to $17 \%$. In L. bulgaricus 859 and L. bulgaricus YIB2 single-culture groups, peptides from $\mathrm{CN}-\beta$ accounted for $54.3 \%$ and $60.8 \%$, respectively, suggesting that the $L$. bulgaricus strain preferred to digest $\mathrm{CN}-\beta$. The percentage of peptides from $\alpha_{\mathrm{S}_{1}} \mathrm{CN}$ in $L$. bulgaricus 859 and L. bulgaricus YIB2 groups was in the second position, falling into the range of 20 to $25 \%$. Peptides from $\alpha_{S_{2}}-\mathrm{CN}$ and $\kappa$-CN showed similar percentages, 8 to $10 \%$.

\section{Visualization of Casein Hydrolysis Patterns in Mono- and Coculture Groups}

With the visualization tool (Manguy et al., 2017), peptide coverage on precursor casein, $\alpha_{\mathrm{S}^{-}} \mathrm{CN}, \alpha_{\mathrm{S} 2}-\mathrm{CN}$, $\mathrm{CN}-\beta$, and $\kappa-\mathrm{CN}$ in mono- and coculture groups is clearly displayed in Figure 1.

As shown in Figure 1A, distribution of peptides from hydrolyzed $\alpha_{\mathrm{S}_{1}} \mathrm{CN}$ in the Strep. thermophilus group was generally similar to that of the L bulgaricus group, except for a higher count of overlapping peptides with a higher sum of intensities at C terminal in the Strep. thermophilus groups. When L. bulgaricus 859 and Strep. thermophilus were cocultured with $L b$. brevis, the $\alpha_{S^{-}}$ CN hydrolyzation pattern was not influenced. For $L$. bulgaricus YIB2, a higher count of peptides with a higher sum of intensities (amino acid position 38-45, approximately) was observed in the coculture group compared with the monoculture group.

As shown in Figure 1B, Strep. thermophilus and $L$. bulgaricus displayed distinct profiles on precursor casein $\mathrm{CN}-\beta$, and overall differences in peptide intensity were also clearly observed. The peptide count and intensity from the Strep. thermophilus group were much lower than those of the $2 \mathrm{~L}$. bulgaricus groups, which was consistent with the analysis results in Table 2 . 


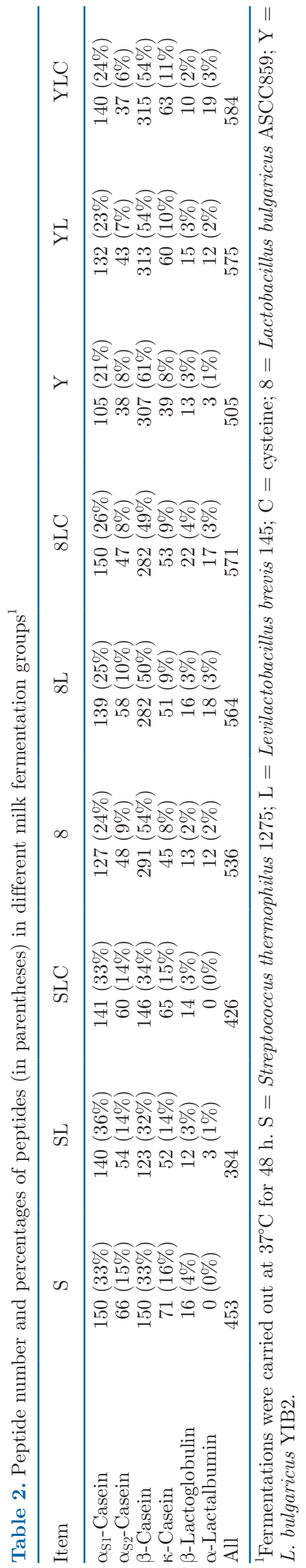

When L. bulgaricus or Strep. thermophilus were cocultured with $L b$. brevis, the overall $\mathrm{CN}-\beta$ hydrolyzation pattern was not influenced. However, a lower count of peptides (amino acid position 180-220, approximately) was observed in the SL group in comparison with the S group, whereas the peptide reduction did not appear in $L$. bulgaricus and $L b$. brevis coculture groups.

As shown in Figure 1C, Strep. thermophilus and L. bulgaricus displayed distinct profiles on precursor casein $\alpha_{\mathrm{S}_{2}}$-CN. For the Strep. thermophilus group, a high count of overlapping peptides was found at the C terminal, whereas for the L. bulgaricus 859 group, a high count of overlapping peptides with a high sum of intensities was found at amino acid positions 115 to 125 . The peptigram for the $L$. bulgaricus YIB2 group was similar to that of the L. bulgaricus 859 group, except for a low sum of intensities at amino acid positions 115 to 125. When L. bulgaricus or Strep. thermophilus were cocultured with $L b$. brevis, overall $\alpha_{\mathrm{S}_{2}}-\mathrm{CN}$ hydrolyzation pattern was not significantly influenced. However, the count of peptides in SL declined compared with the $\mathrm{S}$ group; specifically, a lower count of peptides (amino acid positions 115-140 and 180-220, approximately) was observed in the SL group. However, the reduction of peptide count did not appear in the $L$. bulgaricus and $L b$. brevis coculture groups; conversely, the $\alpha_{S_{2}}-\mathrm{CN}$ hydrolysis level was even higher at amino acid positions 185 to 200 in L. bulgaricus and Lb. brevis coculture groups.

As shown in Figure 1D, Strep. thermophilus and $L$. bulgaricus displayed distinct profiles on precursor casein $\kappa$-CN. For the Strep. thermophilus groups, peptides were mainly distributed at the $\mathrm{C}$ terminal, whereas peptides were evenly distributed in the green shaded area for 2 L. bulgaricus groups, and the peptide coverage for the $L$. bulgaricus YIB2 group was similar to that of L. bulgaricus 859. When L. bulgaricus or Strep. thermophilus were cocultured with $L b$. brevis, overall $\kappa-\mathrm{CN}$ hydrolyzation pattern was not significantly influenced. However, the count of peptides in SL declined compared with the S group, whereas the peptide count was higher in the L. bulgaricus and $L b$. brevis coculture groups, especially for the L. bulgaricus YIB2 coculture group.

\section{Effects of PLP, WPH, and Cysteine on Improving GABA Production in SL-Fermented Milk in Presence of MSG}

Monosodium glutamate was found to be necessary for GABA production by Lb. brevis 145 (Supplemental Table S1, https://doi.org/10.6084/m9.figshare.17701424.v1); thus, the effects of PLP, WPH, and cysteine on GABA production in the presence of $1 \mathrm{~g} / \mathrm{L}$ MSG were exam- 

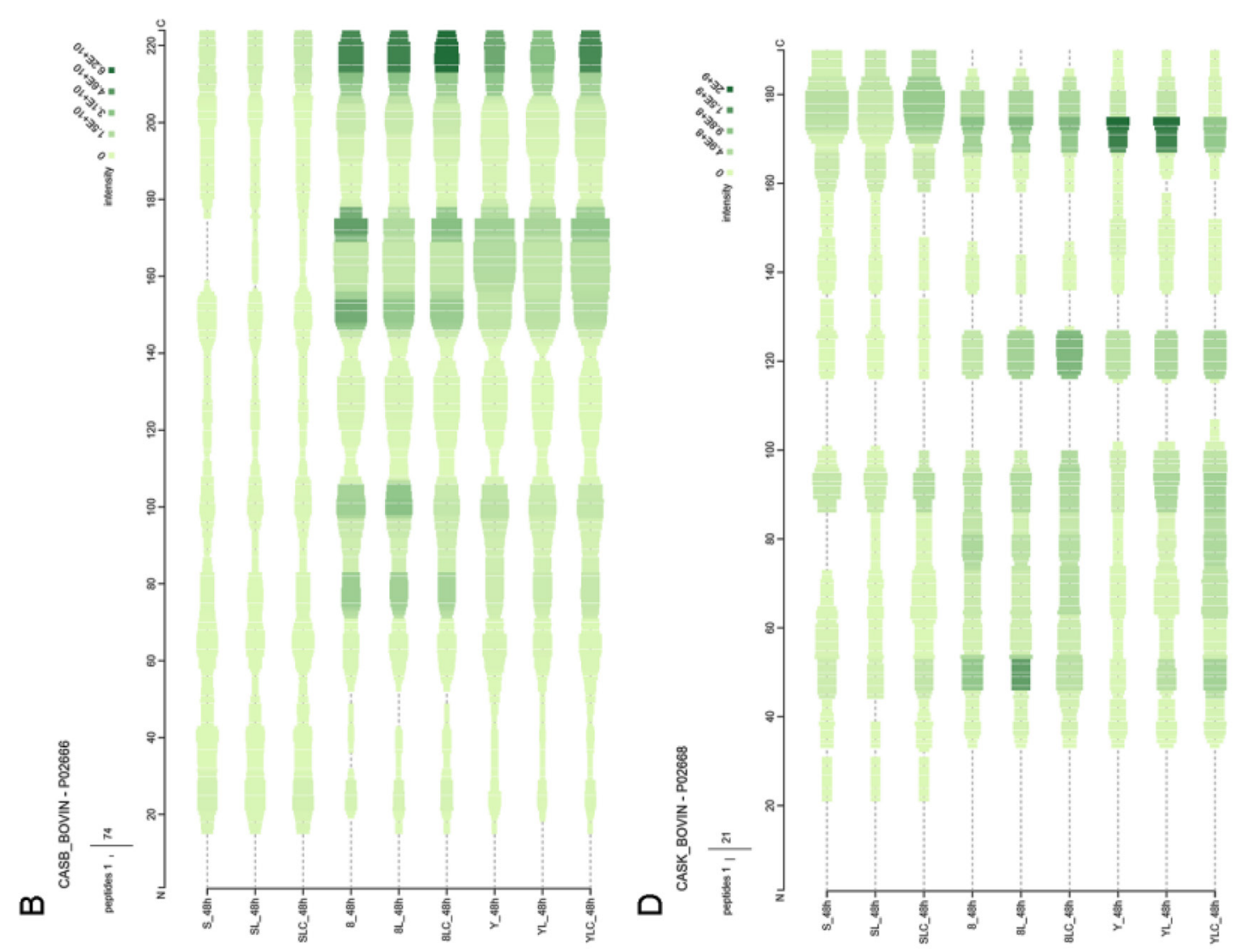

$\Xi$

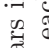

(2)

ॠत

둥

递.

월

.

월

of

구웡

줄

물

争

언에

플

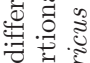

.

西要

곡

㐘

혹

สี 웅

0.

경명
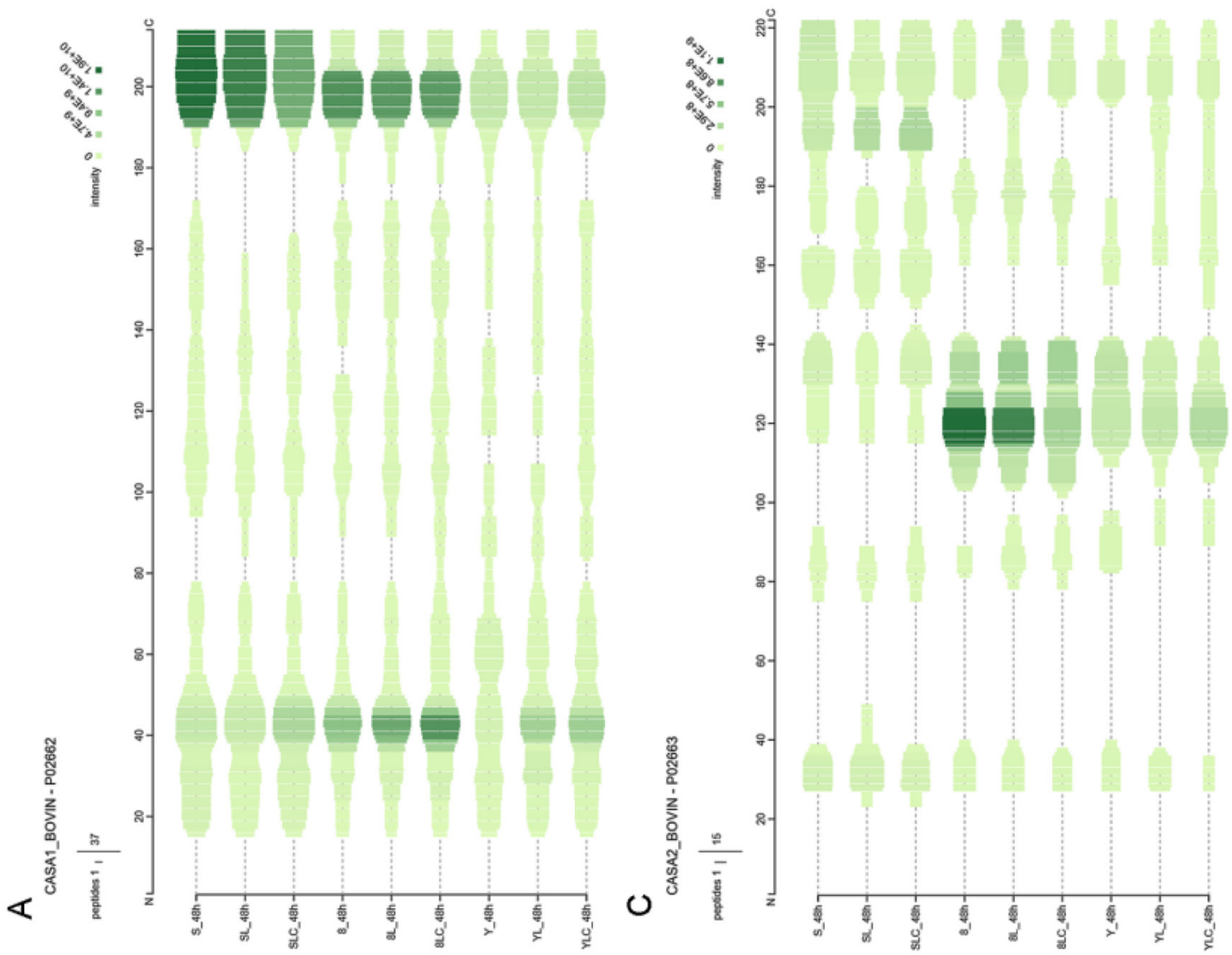

踏

\%

造0

ब्रे है

毒: 莺

ํํㅇำ

c)

$\leq$ 吅

궁휴

क्ष

पू

की है

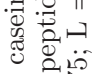

苏姑

卷节

है

혀 욜

80.

ํํำ

웡

웅

范离

가에

范范

些表. 
Table 3. Effects of pyridoxal phosphate (PLP), whey protein hydrolysate (WPH), and cysteine (Cys) on $\gamma$-aminobutyric acid (GABA) production in presence of $1 \mathrm{~g} / \mathrm{L}$ monosodium glutamate $(\mathrm{MSG})^{1}$

\begin{tabular}{|c|c|c|}
\hline Additive & $\begin{array}{l}\text { Residual } \\
\text { MSG (g/L) }\end{array}$ & $\begin{array}{c}\text { GABA } \\
\text { production }(\mathrm{g} / \mathrm{L})\end{array}$ \\
\hline Blank milk & $0.60 \pm 0.010$ & $0.13 \pm 0.004^{\mathrm{a}}$ \\
\hline $25 \mathrm{mg} / \mathrm{L}$ Cys & $0.14 \pm 0.017$ & $0.55 \pm 0.003^{\mathrm{b}}$ \\
\hline $50 \mathrm{mg} / \mathrm{L}$ Cys & $0.11 \pm 0.004$ & $0.52 \pm 0.019^{\mathrm{b}}$ \\
\hline $75 \mathrm{mg} / \mathrm{L}$ Cys & $0.10 \pm 0.000$ & $0.56 \pm 0.029^{\mathrm{b}}$ \\
\hline $100 \mathrm{mg} / \mathrm{L}$ Cys & $0.09 \pm 0.001$ & $0.58 \pm 0.016^{\mathrm{b}}$ \\
\hline $200 \mathrm{mg} / \mathrm{L}$ Cys & $0.12 \pm 0.005$ & $0.47 \pm 0.025^{\mathrm{c}}$ \\
\hline $2 \mathrm{~g} / \mathrm{L} \mathrm{WPH}$ & ND & ND \\
\hline $4 \mathrm{~g} / \mathrm{L} W P H$ & ND & ND \\
\hline $6 \mathrm{~g} / \mathrm{L} \mathrm{WPH}$ & ND & ND \\
\hline $8 \mathrm{~g} / \mathrm{L}$ WPH & ND & ND \\
\hline $10 \mathrm{~g} / \mathrm{L} \mathrm{WPH}$ & ND & ND \\
\hline $0.01 \mathrm{~m} M$ PLP & ND & ND \\
\hline $0.02 \mathrm{~m} M$ PLP & ND & ND \\
\hline $0.03 \mathrm{~m} M$ PLP & ND & ND \\
\hline $0.04 \mathrm{~m} M$ PLP & ND & ND \\
\hline $0.05 \mathrm{~m} M \mathrm{PLP}$ & ND & ND \\
\hline
\end{tabular}

${ }^{\mathrm{a}-\mathrm{c}}$ Values with different letters are significantly different $(P<0.05)$. ${ }^{1}$ Fermentations were carried out at $37^{\circ} \mathrm{C}$ for $48 \mathrm{~h}$. Blank milk $=$ only MSG added. ND = not detectable.

ined. As shown in Table 3, cysteine supplementation increased GABA content and simultaneously decreased MSG level. In the presence of $50 \mathrm{mg} / \mathrm{L}$ cysteine, GABA production increased from $0.13 \mathrm{~g} / \mathrm{L}$ to $0.58 \mathrm{~g} / \mathrm{L}$ in fermented milk; meanwhile, the remnant MSG decreased to $0.12 \mathrm{~g} / \mathrm{L}$. The residual MSG was higher when cysteine concentration was at either $25 \mathrm{mg} / \mathrm{L}$ or more than $200 \mathrm{mg} / \mathrm{L}$. Combining GABA production and residual MSG, 50 to $100 \mathrm{mg} / \mathrm{L}$ cysteine was regarded as appropriate range for GABA production. In our research, PLP and WPH had no influence on GABA production in the presence of MSG (Table 3).

\section{Influence of Different Concentrations of Cysteine and MSG on Improving GABA Production in SL-Fermented Milk}

To confirm whether cysteine has greater influence on GABA production, the effects of different concentrations of cysteine $(0,50,100,150,200$, or $300 \mathrm{mg} / \mathrm{L})$ and MSG $(0,2,4,6,8$, or $10 \mathrm{~g} / \mathrm{L})$ on improving GABA production after 48 -h milk fermentation at $37^{\circ} \mathrm{C}$ were examined. The results in Table 4 showed that in the cocultured RSM with Strep. thermophilus 1275 and $L b$. brevis 145 with cysteine at $50 \mathrm{mg} / \mathrm{L}$, MSG ranging from $2,4,6,8$, and $10 \mathrm{~g} / \mathrm{L}$ could be converted into 1.03, 2.11, $3.14,3.93$, and $4.80 \mathrm{~g} / \mathrm{L}$ GABA, respectively. Meanwhile, the corresponding amounts of residual MSG after fermentation were $0.03,0.04,0.08,0.15$, and $0.19 \mathrm{~g} / \mathrm{L}$, respectively. In the presence of cysteine, the highest level of GABA after 48-h milk fermentation was 4.80 $\mathrm{g} / \mathrm{L}(46.6 \mathrm{mM})$, and the maximum GABA conversion ratio from MSG during milk fermentation was $86.61 \%$ at the level of $4 \mathrm{~g} / \mathrm{L} \mathrm{MSG}$ supplementation (Table 4). Without cysteine, the highest level of GABA after 48-h milk fermentation was $0.18 \mathrm{~g} / \mathrm{L}(1.75 \mathrm{mM})$, and the maximum GABA conversion ratio was only $7.38 \%$ at the level of $6 \mathrm{~g} / \mathrm{L}$ MSG supplementation. Moreover, supplementation of different concentrations of cysteine showed no significant influence on GABA yield.

\section{Determination of Relationship Between MSG Utilization and GABA Production in Presence of Cysteine}

To understand the association between GABA production and MSG utilization, a $48 \mathrm{~h}$-course of RSM fermentation with cocultured Lb. brevis and Strep. themophilus with or without cysteine was carried out at $37^{\circ} \mathrm{C}$ in presence of $2 \mathrm{~g} / \mathrm{L}$ MSG. The results in Figure 2 showed that without cysteine, GABA production increased slowly during the 48 -h fermentation, reaching $0.2 \mathrm{~g} / \mathrm{L}$, and MSG concentration simultaneously decreased at a slow rate similar to that of GABA production. For the fermentation batch with cysteine (50 $\mathrm{mg} / \mathrm{L})$, GABA production dramatically increased from $0.061 \mathrm{~g} / \mathrm{L}$ to $0.908 \mathrm{~g} / \mathrm{L}$ after $48 \mathrm{~h}$ of fermentation. Accordingly, the residual MSG concentration declined, and MSG utilization was proportionate to GABA production. The results systematically confirmed that MSG was the major reactive substrate for GABA production and cysteine could significantly promote GABA production.

\section{Changes in Cell Counts, Lactic Acid Production, pH, and Lactose Utilization in Presence of Cysteine}

Viable cell counts, lactose and galactose utilization, lactic acid production, and $\mathrm{pH}$ values were determined during 48-h fermentation. The results in Figure 3B showed that the exponential growth period of bacteria in both batches was from 3 to $6 \mathrm{~h}$, and cell counts of Lb. brevis 145 increased from $6.7 \times 10^{7}$ to $5.78 \times 10^{8}$ $\mathrm{cfu} / \mathrm{mL}$ in the SL group, and from $6.94 \times 10^{8}$ to 7.02 $\times 10^{8} \mathrm{cfu} / \mathrm{mL}$ in the SLC group. After 12-h fermentation, viable cell counts of $L b$. brevis 145 decreased from $5.78 \times 10^{8}$ to $1.94 \times 10^{8} \mathrm{cfu} / \mathrm{mL}$ in the SL group but declined from $7.02 \times 10^{8}$ to $3.28 \times 10^{8} \mathrm{cfu} / \mathrm{mL}$ in the SLC group. Moreover, it was observed that $L b$. brevis 145 cell counts in the SLC group were always higher than those in the SL group during 48-h fermentation.

As shown in Figure 3C, lactic acid accumulated during the first $6 \mathrm{~h}$ of fermentation, and it was observed that the amount of lactic acid produced in the SLC group was always higher than that in the SL group. However, pH values for the SL and SLC batches were 
Table 4. Effects of different concentration of cysteine and monosodium glutamate (MSG) on improving $\gamma$-aminobutyric acid (GABA) production ${ }^{1}$

\begin{tabular}{|c|c|c|c|c|}
\hline $\begin{array}{l}\text { MSG level } \\
(\mathrm{g} / \mathrm{L})\end{array}$ & $\begin{array}{c}\text { Cysteine } \\
\text { level }(\mathrm{mg} / \mathrm{L})\end{array}$ & $\begin{array}{c}\text { Residual } \\
\text { MSG (g/L) }\end{array}$ & $\begin{array}{c}\text { GABA } \\
\text { production }(\mathrm{g} / \mathrm{L})\end{array}$ & $\begin{array}{l}\text { GABA conversion } \\
\text { ratio from MSG }(\%)\end{array}$ \\
\hline \multirow[t]{6}{*}{2} & 0 & $1.75 \pm 0.228$ & $0.06 \pm 0.061^{\mathrm{a}}$ & 4.92 \\
\hline & 50 & $0.03 \pm 0.002$ & $1.03 \pm 0.011^{\mathrm{b}}$ & 84.55 \\
\hline & 100 & $0.05 \pm 0.016$ & $1.00 \pm 0.036^{\mathrm{b}}$ & 82.09 \\
\hline & 150 & $0.08 \pm 0.002$ & $0.98 \pm 0.046^{\mathrm{b}}$ & 80.45 \\
\hline & 200 & $0.09 \pm 0.004$ & $0.99 \pm 0.014^{\mathrm{b}}$ & 81.27 \\
\hline & 300 & $0.13 \pm 0.004$ & $0.94 \pm 0.051^{\mathrm{b}}$ & 77.17 \\
\hline \multirow[t]{6}{*}{4} & 0 & $3.70 \pm 0.199$ & $0.13 \pm 0.103^{\mathrm{a}}$ & 5.33 \\
\hline & 50 & $0.03 \pm 0.001$ & $2.10 \pm 0.107^{\mathrm{b}}$ & 86.19 \\
\hline & 100 & $0.04 \pm 0.003$ & $2.11 \pm 0.118^{\mathrm{b}}$ & 86.61 \\
\hline & 150 & $0.05 \pm 0.002$ & $2.02 \pm 0.020^{\mathrm{b}}$ & 82.91 \\
\hline & 200 & $0.09 \pm 0.016$ & $1.98 \pm 0.059^{\mathrm{b}}$ & 81.27 \\
\hline & 300 & $0.14 \pm 0.010$ & $2.07 \pm 0.003^{\mathrm{b}}$ & 84.96 \\
\hline \multirow[t]{6}{*}{6} & 0 & $4.74 \pm 0.518$ & $0.18 \pm 0.126^{\mathrm{a}}$ & 7.38 \\
\hline & 50 & $0.08 \pm 0.042$ & $3.14 \pm 0.039^{\mathrm{b}}$ & 85.92 \\
\hline & 100 & $0.04 \pm 0.003$ & $2.83 \pm 0.184^{\mathrm{b}}$ & 77.44 \\
\hline & 150 & $0.05 \pm 0.001$ & $2.99 \pm 0.102^{\mathrm{b}}$ & 81.82 \\
\hline & 200 & $0.07 \pm 0.001$ & $3.10 \pm 0.015^{\mathrm{b}}$ & 84.83 \\
\hline & 300 & $0.15 \pm 0.001$ & $3.00 \pm 0.069^{\mathrm{b}}$ & 82.09 \\
\hline \multirow[t]{6}{*}{8} & 0 & $7.26 \pm 0.487$ & $0.12 \pm 0.051^{\mathrm{a}}$ & 2.46 \\
\hline & 50 & $0.11 \pm 0.010$ & $3.84 \pm 0.041^{\mathrm{b}}$ & 78.81 \\
\hline & 100 & $0.18 \pm 0.043$ & $3.89 \pm 0.021^{\mathrm{b}}$ & 79.83 \\
\hline & 150 & $0.09 \pm 0.014$ & $3.78 \pm 0.119^{\mathrm{b}}$ & 77.58 \\
\hline & 200 & $0.14 \pm 0.028$ & $3.86 \pm 0.399^{\mathrm{b}}$ & 79.22 \\
\hline & 300 & $0.15 \pm 0.000$ & $3.93 \pm 0.088^{\mathrm{b}}$ & 80.65 \\
\hline \multirow[t]{6}{*}{10} & 0 & $8.93 \pm 0.172$ & $0.10 \pm 0.065^{\mathrm{a}}$ & 1.65 \\
\hline & 50 & $0.24 \pm 0.059$ & $4.53 \pm 0.381^{\mathrm{b}}$ & 74.37 \\
\hline & 100 & $0.20 \pm 0.019$ & $4.65 \pm 0.014^{\mathrm{b}}$ & 76.35 \\
\hline & 150 & $0.13 \pm 0.048$ & $4.76 \pm 0.321^{\mathrm{b}}$ & 78.15 \\
\hline & 200 & $0.19 \pm 0.071$ & $4.80 \pm 0.126^{\mathrm{b}}$ & 78.81 \\
\hline & 300 & $0.29 \pm 0.060$ & $3.93 \pm 0.358^{\mathrm{c}}$ & 64.52 \\
\hline
\end{tabular}

${ }^{\mathrm{a}-\mathrm{c}}$ Values with different letters are significantly different $(P<0.05)$.

${ }^{1}$ Fermentations were carried out at $37^{\circ} \mathrm{C}$ for $48 \mathrm{~h}$.

similar; $\mathrm{pH}$ dropped from 6.6 to 4.8 during the first 6 $\mathrm{h}$ of fermentation, followed by a slight decline, finally remaining steady at 4.3 .

As shown in Figure 3D, no significant differences in lactose and galactose levels occurred between the SL and SLC groups during 48-h fermentation, indicating that cysteine showed no significant effect on sugar utilization. During early 6 -h fermentation, the lactose level decreased from 49.89 to $8.82 \mathrm{~g} / \mathrm{L}$, and galactose concentration went up from 0.72 to $15.28 \mathrm{~g} / \mathrm{L}$ in the SL group; lactose level decreased from 50.01 to $6.43 \mathrm{~g} / \mathrm{L}$, and galactose concentration went up from 0.81 to 14.62 $\mathrm{g} / \mathrm{L}$ in the SLC group. After 6-h fermentation, lactose levels in both groups remained unchanged, whereas galactose utilization increased.

\section{Effect of Cysteine on Casein Hydrolysis Patterns}

As shown in Figure $1 \mathrm{~A}-\mathrm{D}$, there were no significant differences in $\alpha_{\mathrm{S}^{-}} \mathrm{CN}, \alpha_{\mathrm{S} 2}-\mathrm{CN}, \mathrm{CN}-\beta$, and $\kappa-\mathrm{CN}$ hydrolyzation patterns for Strep. thermophilus and $L$. bulgaricus in coculture with $L b$. brevis with or without cysteine.

\section{Positive Effect of Sulfhydryl Group-Containing Chemicals on GABA Production in SL-Fermented Milk}

To investigate whether the sulfhydryl group in cysteine exerted a positive effect on GABA production, sulfur-containing chemicals, including cystine, methionine, reduced glutathione, and oxidized glutathione, were individually supplemented in milk fermentation to determine their effects on GABA production. The results in Figure 3A showed that addition of cystine, reduced glutathione, and oxidized glutathione showed positive effects similar to cysteine in improving GABA production, with GABA reaching $0.6 \mathrm{~g} / \mathrm{L}$ after 48-h fermentation. Conversely, methionine was observed to inhibit GABA production.

\section{Improvement of GABA Production by Lb. brevis Cocultured with Strep. thermophilus and $L$. bulgaricus YIB2 in Presence of Cysteine}

As shown in Figure 4, when L. bulgaricus YIB2 was combined with $L b$. brevis $145,0.08 \mathrm{~g} / \mathrm{L}$ of GABA was 


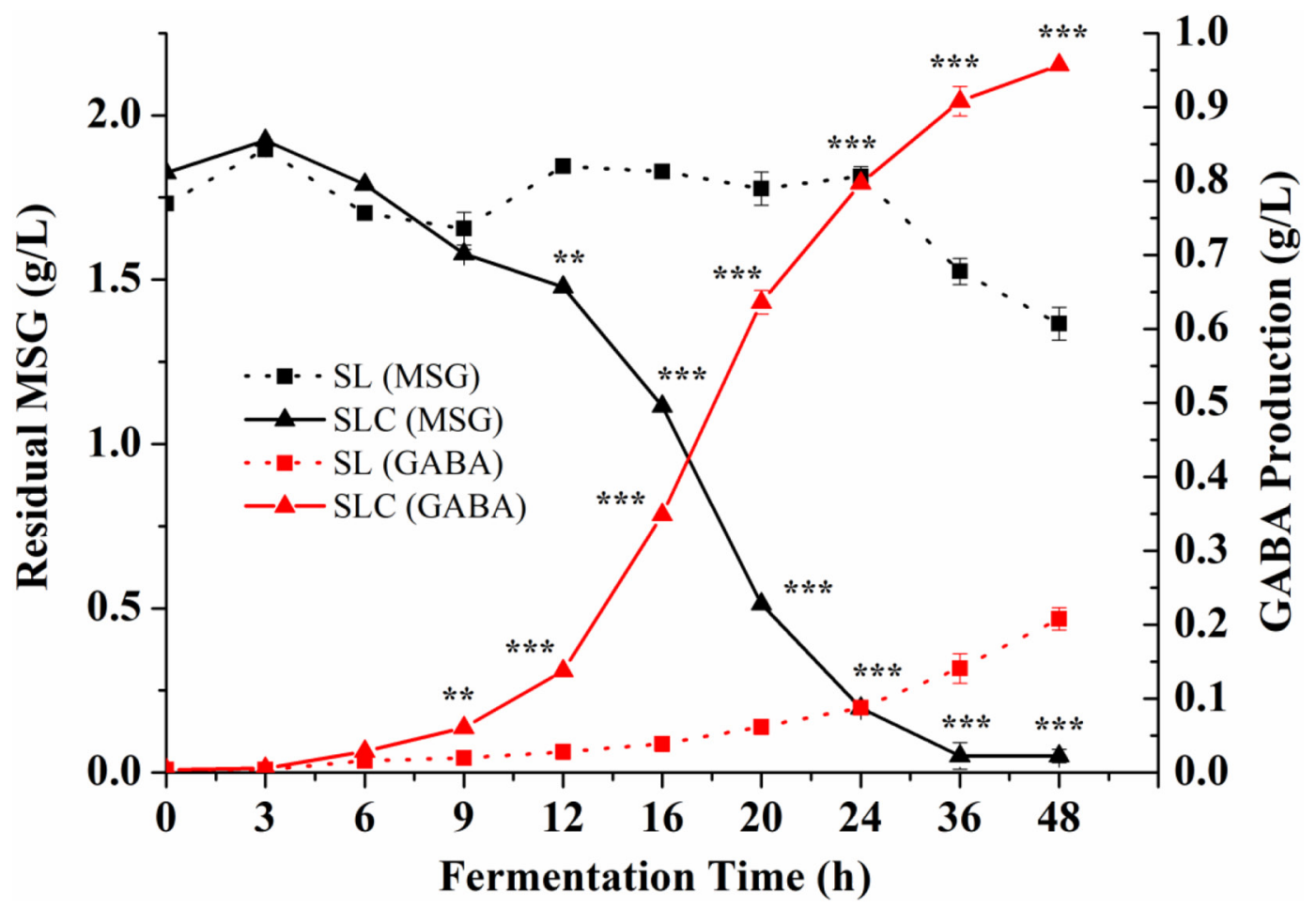

Figure 2. Monosodium glutamate (MSG) consumption and $\gamma$-aminobutyric acid (GABA) production by SL coculture with or without cysteine during 48-h milk fermentation. MSG level exogenously supplemented in milk medium was $2 \mathrm{~g} / \mathrm{L}$. SL = Streptococcus thermophilus 1275 + Levilactobacillus brevis $145 .{ }^{*} P<0.01 ;{ }^{* * *} P<0.001$. The experiment was carried out in triplicate, and data are presented as mean \pm SD.

produced; supplementation of cysteine in the 2-bacteria coculture system showed no effect on GABA production. When Strep. thermophilus 1275 was added in the 2-bacteria coculture batch, the GABA level reached $0.16 \mathrm{~g} / \mathrm{L}$. Supplementation with cysteine in the 3-bacteria coculture system significantly improved GABA production at $0.99 \mathrm{~g} / \mathrm{L}$.

Lactobacillus bulgaricus 756 was also combined with Lb. brevis 145 to improve GABA production; however, no GABA was produced. Supplementation with cysteine in the 2-bacteria coculture system improved GABA production to $0.12 \mathrm{~g} / \mathrm{L}$. When Strep. thermophilus 1275 was added in the 2-bacteria coculture batch, GABA production reached $0.14 \mathrm{~g} / \mathrm{L}$, and supplementation of cysteine in the 3 -bacteria coculture system significantly improved GABA production at $0.55 \mathrm{~g} / \mathrm{L}$.

When $L$. bulgaricus 859 was combined with $L b$. brevis 145 to improve GABA production, no GABA was produced. Supplementation of cysteine in the 2-bacteria coculture system increased GABA production only to $0.05 \mathrm{~g} / \mathrm{L}$. When Strep. thermophilus 1275 was added in the 2-bacteria coculture batch, GABA concentration reached $0.02 \mathrm{~g} / \mathrm{L}$, and supplementation of cysteine in the 3-bacteria coculture fermentation system showed no effect on GABA production.

\section{DISCUSSION}

Wu et al. (2015) found that nonproteolytic Lb. brevis 145 in coculture with Strep. thermophilus, but not $L$. bulgaricus, was able to produce GABA during milk fermentation in the presence of MSG. To understand why only Strep. thermophilus, not L. bulgaricus, was able to help $L b$. brevis 145 survive in milk and produce GABA during milk fermentation, LC-MS/MS was performed to investigate whether different casein hydrolysis patterns by L. bulgaricus and Strep. thermophilus contributed to the feasibility and efficiency of coculture systems for GABA production. Specific casein hydrolyzation patterns could not be explored with SDS-PAGE alone (Abraham et al., 1993); thus, LC-MS/MS was applied to determine the peptide profiles from different bacteria, as well as to compare the differences in peptide profiles among different groups to explore the mechanisms behind the coculture. Our results showed that L. bulgaricus and Strep. thermophilus showed different preferences to digest $\alpha_{\mathrm{S}^{-}} \mathrm{CN}, \alpha_{\mathrm{S}^{-}} \mathrm{CN}, \mathrm{CN}-\beta$, and $\kappa-\mathrm{CN}$. In the Strep. thermophilus 1275 single-culture group, CN- $\beta$ and $\alpha_{\mathrm{S} 1}-\mathrm{CN}$ contributed to $33 \%$ of total peptides, respectively, followed by $\kappa-\mathrm{CN}$ and $\alpha_{\mathrm{S}_{2}} \mathrm{CN}$. Miclo et al. (2012) reported that $\mathrm{CN}-\beta$ was preferentially hydro- 
A

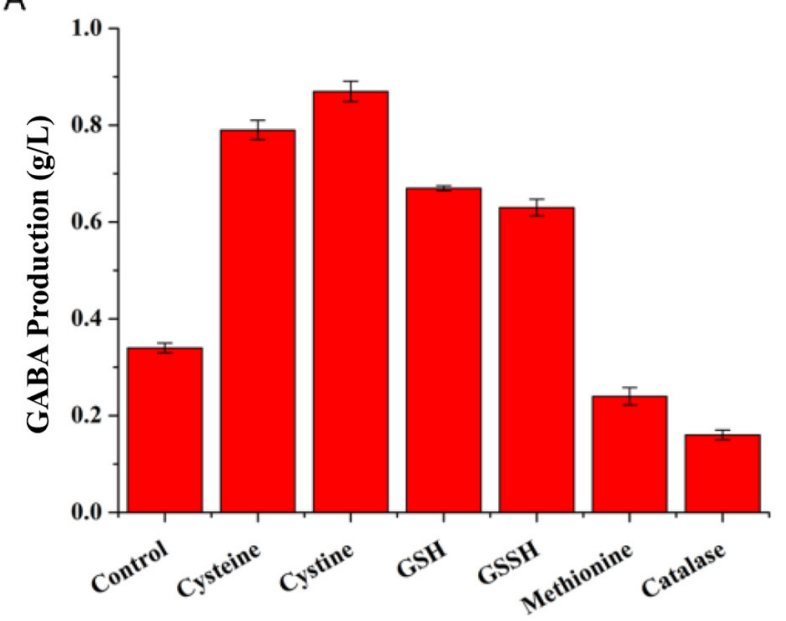

C

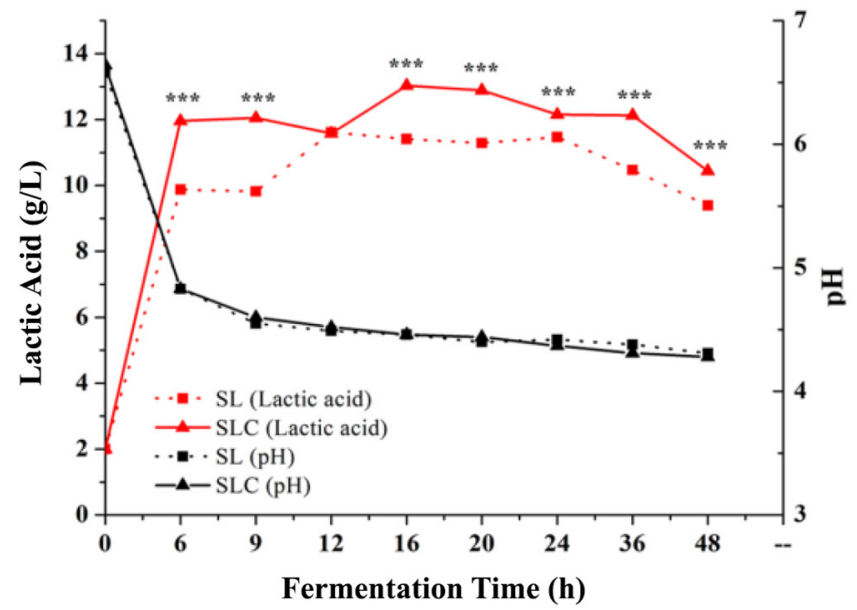

B

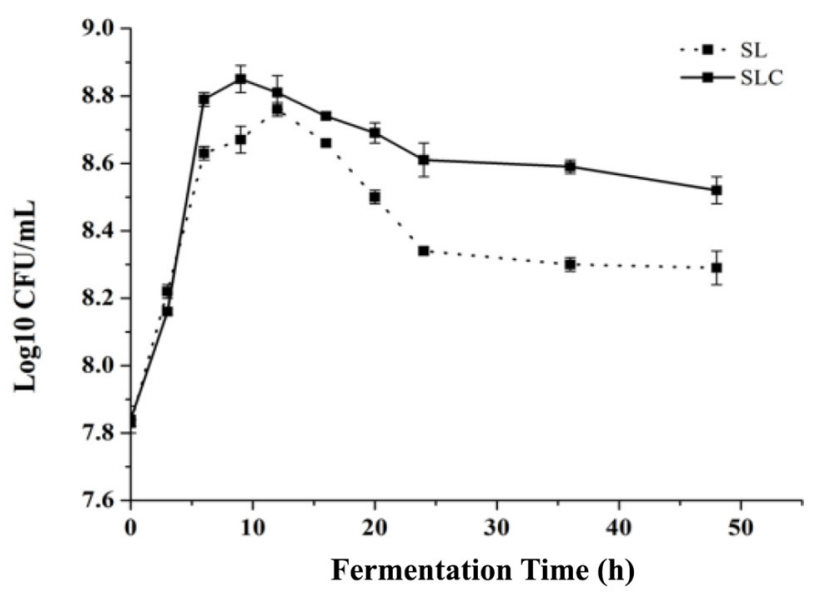

D

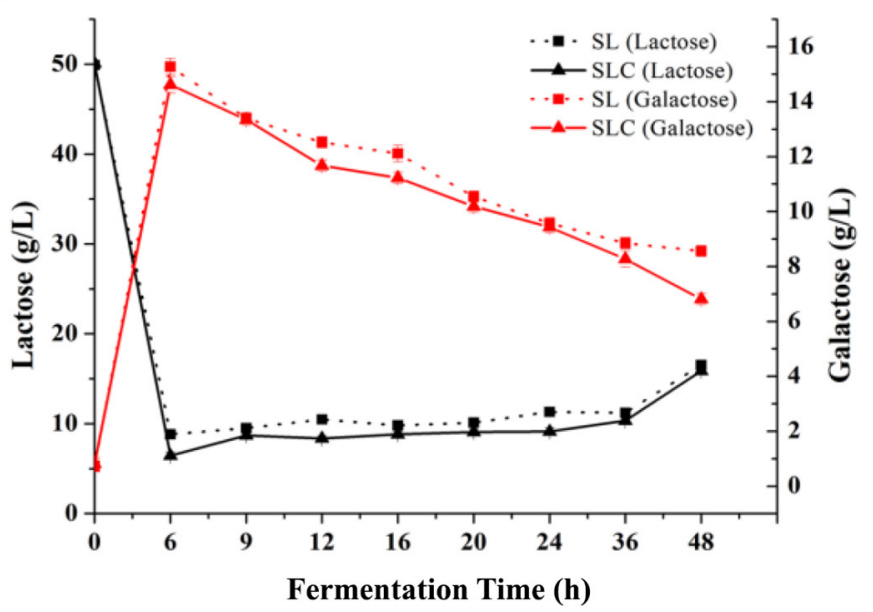

Figure 3. Changes of pH and metabolites during 48-h milk fermentation. (A) Effect of sulfur group-containing chemicals on GABA improvement; (B) cell counts of Levilactobacillus brevis 145; (C) $\mathrm{pH}$ and lactic acid production; (D) lactose and galactose utilization. S = Streptococcus thermophilus $1275 ; \mathrm{L}=$ Lb. brevis $145 ; \mathrm{C}=$ cysteine; $\mathrm{GSH}=$ reduced glutathione; GSSH $=$ oxidized glutathione. ${ }^{* * *} P<0.001$. The experiment was carried out in triplicate, and data are presented as mean $\pm \mathrm{SD}$.

lyzed by Strep. thermophilus strains, however, followed by $\alpha_{\mathrm{S}^{2}} \mathrm{CN}$ and then $\alpha_{\mathrm{S} 1}$-CN, which exhibited a little difference compared with our results. For L. bulgaricus, peptide profiles for L. bulgaricus 859 and L. bulgaricus YIB2 single-culture groups showed that $\mathrm{CN}-\beta$ was the most susceptible casein component to be degraded, followed by the $\alpha_{\mathrm{S}^{-}} \mathrm{CN}$ and $\kappa-\mathrm{CN}$ fractions, which was in agreement with the previous study (Chandan et al., 1982). Importantly, comparative analysis of peptide profiles among different groups showed that peptide numbers increased in the $L$. bulgaricus and $L b$. brevis coculture batch but decreased in the SL coculture batch compared with the corresponding monoculture groups. Moreover, Xiao et al. (2020) reported that particular peptides hydrolyzed by Strep. thermophilus ASCC1275 were transported and biodegraded with peptidase in
$L b$. brevis 145 to meet the growth needs of the latter, all of which could explain why Strep. thermophilus, but not $L$. bulgaricus, was capable of coculturing with $L b$. brevis to produce GABA in milk.

One problem pertaining to the SL coculture system is that the content of GABA in fermented milk was below the physiological level for humans (Abdou et al., 2006), and the high level of residual MSG may bring an undesirable taste. The aim of our research was to explore methods to increase GABA and reduce MSG content in fermented milk. We selected MSG, PLP, WPH and cysteine for our research. According to the genome map, an intact gad operon was identified in Lb. brevis 145 of plant origin (Wu et al., 2017), and the deficiency of the glutamate dehydrogenase-encoding gene $(g d h A)$ to form glutamate was also observed in Lb. brevis 145 . Hence, 
exogenous supplementation of MSG was required for the decarboxylation reaction to produce GABA. It was observed that the maximum GABA conversion ratio reached $7.38 \%$ without cysteine, and the GABA conversion ratio declined when MSG addition exceeded 6 $\mathrm{g} /$ L. Pyridoxal phosphate was reported as an essential co-factor for the GAD enzyme (Li et al., 2016). Shan et al. (2015) found that the yield of GABA reached the highest level at $165.6 \mu \mathrm{g} / 100 \mathrm{~g}$ after about $20 \mu \mathrm{M}$ of PLP supplementation. However, in our research, PLP supplementation had no effect on GABA improvement. Whey protein hydrolysate was reported to promote the viability and growth of starter and probiotic bacteria in yogurt (Dąbrowska et al., 2017) by directly providing peptides for growth in milk and producing a high level of GABA. However, our research showed that WPH did not influence GABA production by Lb. brevis 145 in coculture with Strep. thermophilus 1275 . Wu et al. (2015) reported that Strep. thermophilus 1275 encodes one intact PrtS (T303_05205), which is involved in the cleavage of casein to oligopeptides, and an abundance of intracellular protease and peptidase was also found in Strep. thermophilus 1275, all of which helped Strep. thermophilus 1275 cells break down oligopeptides into free amino acids for cellular metabolism or direct utilization by the cocultured bacteria. Hence, there was no need to add extra WPH for growth of Lb. brevis 145 in milk.

Cysteine is not available in most milk proteins $(\alpha-$ and $\beta$-caseins) in their amino acid composition (Gordon et al., 1949), and may act as an essential amino acid for $L b$. brevis to enhance growth and consequent GABA production. Dave and Shah (1997) also reported that cysteine was able to improve the viability of yogurt and probiotic bacteria in yogurt by lowering redox potential. Therefore, cysteine was expected to increase the bacteria cell counts in milk and thus GABA yield. In our study, a small amount of cysteine supplementation was able to increase cell counts, efficiently produce a high level of GABA (4.8 g/L, $46.6 \mathrm{mM})$, and significantly increase the GABA conversion ratio from $5.33 \%$ to $86.61 \%$. Moreover, the residual MSG in all fermented milk groups was minimal, below $0.2 \mathrm{~g} / \mathrm{L}$, which may potentially bring a better taste to GABArich fermented milk. For Levilactobacillus brevis HYE1, the maximum GABA production $(18.60 \mathrm{mM}$ ) was ob-

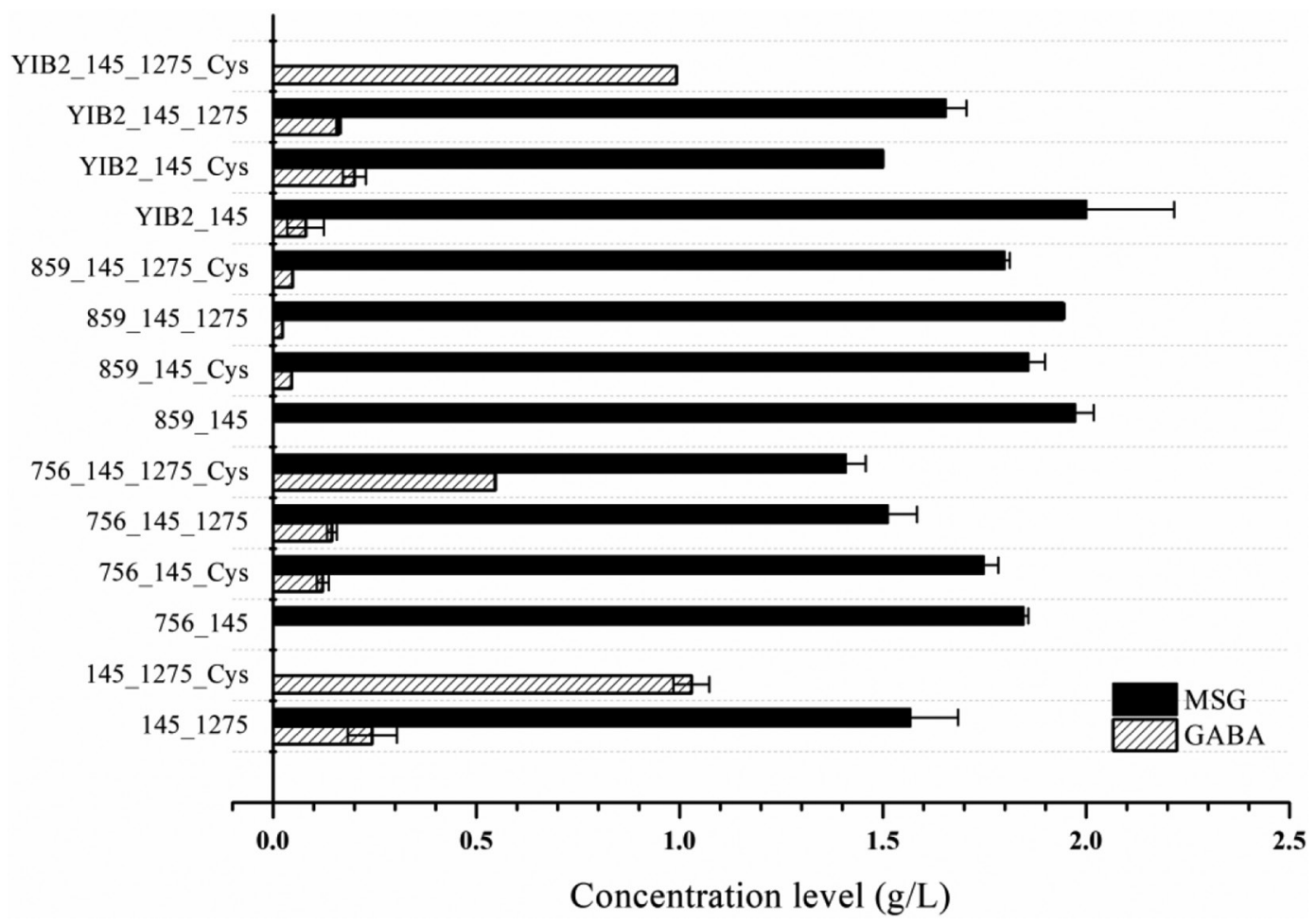

Figure 4. Improvement of $\gamma$-aminobutyric acid (GABA) production by Levilactobacillus brevis cocultured with Streptococcus thermophilus and Lactobacillus bulgaricus YIB2 in presence of cysteine. We added $2 \mathrm{~g} / \mathrm{L}$ monosodium glutamate (MSG) in every treatment, and fermentations were carried out at $37^{\circ} \mathrm{C}$ for 48 h. $756=$ L. bulgaricus ASCC756; $859=$ L. bulgaricus ASCC859; YIB2 $=$ L. bulgaricus YIB2; $145=$ Lb. brevis $145 ; 1275=$ Strep thermophilus ASCC1275; Cys = cysteine. The experiment was carried out in triplicate, and data are presented as mean \pm SD. 
tained with addition of $10 \mathrm{~g} / \mathrm{L}$ MSG in the modified MRS medium (Lim et al., 2017). The maximum yield of GABA from available glutamate by $L b$. brevis 6018 was $75 \%$, with $10 \mathrm{~g} / \mathrm{L}(59 \mathrm{mM})$ MSG formulation in modified MRS (Banerjee et al., 2021). For Lb. brevis CRL 2013, the GABA conversion ratio from MSG in modified MRS was above $90 \%$, and the maximum GABA production reached $258 \mathrm{mM}$ with addition of $267 \mathrm{mM}$ MSG (Cataldo et al., 2020). Compared with methods applying optimization of culture conditions and genetic engineering (Cui et al., 2020), the addition of a small amount of cysteine during milk fermentation is much more efficient and convenient. Additionally, sulfhydryl group-containing chemicals exhibited effects similar to cysteine in improving GABA production. Our work is the first study finding that cysteine showed great effect in improving GABA production by Lb. brevis 145 in coculture with Strep. thermophilus 1275 during milk fermentation, which may have particular interest to dairy industry.

Furthermore, combining Lb. brevis 145 with 2 yogurt bacteria for GABA-rich milk fermentation attracts our attention because this may improve the performance and market competitiveness of functional yogurts in the food industry. In our research, a 3-bacteria coculture system was successfully created for producing GABA-rich milk after fermentation in the presence of cysteine. Each probiotic bacterium offers different and specific health benefits: Lb. brevis 145 may act as a functional dairy starter for GABA production (Wu and Shah, 2017), and L. bulgaricus YIB2 is known for lactose utilization and acidification and for releasing free amino acids such as proline, which could bring a sweet flavor to yogurt (Deutsch et al., 2000). High exopolysaccharide-producing Strep. thermophilus 1275 showed faster growth and acidification rates, resulting in yogurt with low syneresis and high flow behavior (Purwandari et al., 2007), and provided nutrients for the growth of cocultured Lb. brevis in milk fermentation (Xiao et al., 2020).

\section{CONCLUSIONS}

Streptococcus thermophilus and L. bulgaricus showed different casein hydrolysis patterns; Strep. thermophilus, but not L. bulgaricus, was capable of providing peptides for the growth of $L b$. brevis 145 in a coculture batch. Supplementation of cysteine helped achieve GABA-rich milk with a minimum level of residual MSG in the SL coculture group, increasing viable cell counts of $L b$. brevis and lactic acid production, but without influencing casein hydrolysis patterns. Moreover, cysteine significantly improved GABA production when $L$. bulgaricus YIB2 was combined with SL.

\section{ACKNOWLEDGMENTS}

This work was financially supported by the Research Grants Council (RGC) of Hong Kong, project no. 17103618 (Investigation into high $\gamma$-aminobutyric acid producing lactic acid bacteria: Insights into genomics, and transcriptomics) received by the senior author (NPS). We thank Wininnovate-Bio Company (Shenzhen, China) for LC/MS-MS service. Author contributions: NPS received RGC research grant. TT and NPS designed the experiments. TT performed the experiments, analyzed the data, and drafted the manuscript, and NPS edited the manuscript. The authors have not stated any conflicts of interest.

\section{REFERENCES}

Abdou, A. M., S. Higashiguchi, K. Horie, M. Kim, H. Hatta, and H. Yokogoshi. 2006. Relaxation and immunity enhancement effects of $\gamma$-aminobutyric acid (GABA) administration in humans. Biofactors 26:201-208. https://doi.org/10.1002/biof.5520260305.

Abraham, A. G., G. L. De Antoni, and M. C. Añon. 1993. Proteolytic activity of Lactobacillus bulgaricus grown in milk. J. Dairy Sci. 76:1498-1505. https://doi.org/10.3168/jds.S0022-0302(93)77481 -0 .

Banerjee, S., M. Poore, S. Gerdes, D. Nedveck, L. Lauridsen, H. T. Kristensen, H. M. Jensen, P. M. Byrd, A. C. Ouwehand, E. Patterson, and W. Morovic. 2021. Transcriptomics reveal different metabolic strategies for acid resistance and gamma-aminobutyric acid (GABA) production in select Levilactobacillus brevis strains. Microb. Cell Fact. 20:173. https://doi.org/10.1186/s12934-021 $-01658-4$.

Bowery, N. G., and T. G. Smart. 2006. GABA and glycine as neurotransmitters: A brief history. Br. J. Pharmacol. 147(Suppl. 1):S109-S119. https://doi.org/10.1038/sj.bjp.0706443.

Cataldo, P. G., J. M. Villegas, G. S. de Giori, L. Saavedra, and E. M. Hebert. 2020. Enhancement of $\gamma$-aminobutyric acid (GABA) production by Lactobacillus brevis CRL 2013 based on carbohydrate fermentation. Int. J. Food Microbiol. 333:108792. https://doi.org/ 10.1016/j.ijfoodmicro.2020.108792.

Chandan, R., P. Argyle, and G. Mathison. 1982. Action of Lactobacillus bulgaricus proteinase preparations on milk proteins. J. Dairy Sci. 65:1408-1413. https://doi.org/10.3168/jds.S0022 -0302(82)82362-X.

Cherng, S. H., C. Y. Huang, W. W. Kuo, S. E. Lai, C. Y. Tseng, Y. M. Lin, F. J. Tsai, and H. F. Wang. 2014. GABA tea prevents cardiac fibrosis by attenuating TNF-alpha and Fas/FasL-mediated apoptosis in streptozotocin-induced diabetic rats. Food Chem. Toxicol. 65:90-96. https://doi.org/10.1016/j.fct.2013.12.022.

Cui, Y., K. Miao, S. Niyaphorn, and X. Qu. 2020. Production of gamma-aminobutyric acid from lactic acid bacteria: A systematic review. Int. J. Mol. Sci. 21:995. https://doi.org/10.3390/ ijms21030995.

Dąbrowska, A., K. Babij, M. Szołtysik, and J. Chrzanowska. 2017. Viability and growth promotion of starter and probiotic bacteria in yogurt supplemented with whey protein hydrolysate during refrigerated storage. Postepy Hig. Med. Dosw. 71:952-959. https:// doi.org/10.5604/01.3001.0010.5866.

Dave, R. I., and N. P. Shah. 1997. Effect of cysteine on the viability of yoghurt and probiotic bacteria in yoghurts made with commercial starter cultures. Int. Dairy J. 7:537-545. https://doi.org/10.1016/ S0958-6946(97)00053-8.

Deutsch, S.-M., D. Molle, V. Gagnaire, M. Piot, D. Atlan, and S. Lortal. 2000. Hydrolysis of sequenced $\beta$-casein peptides provides new insight into peptidase activity from thermophilic lactic acid bacteria and highlights intrinsic resistance of phosphopeptides. Appl. 
Environ. Microbiol. 66:5360-5367. https://doi.org/10.1128/AEM .66.12.5360-5367.2000.

Ebner, J., A. A. Arslan, M. Fedorova, R. Hoffmann, A. Küçükçetin, and M. Pischetsrieder. 2015. Peptide profiling of bovine kefir reveals 236 unique peptides released from caseins during its production by starter culture or kefir grains. J. Proteomics 117:41-57. https://doi.org/10.1016/j.jprot.2015.01.005.

Gordon, W. G., W. F. Semmett, R. S. Cable, and M. Morris. 1949. Amino acid composition of $\alpha$-casein and $\beta$-casein. J. Am. Chem. Soc. 71:3293-3297. https://doi.org/10.1021/ja01178a006.

Hayakawa, K., M. Kimura, K. Kasaha, K. Matsumoto, H. Sansawa, and Y. Yamori. 2004. Effect of a $\gamma$-aminobutyric acid-enriched dairy product on the blood pressure of spontaneously hypertensive and normotensive Wistar-Kyoto rats. Br. J. Nutr. 92:411-417. https://doi.org/10.1079/BJN20041221.

Jinap, S., and P. Hajeb. 2010. Glutamate. Its applications in food and contribution to health. Appetite 55:1-10. https://doi.org/10.1016/ j.appet.2010.05.002.

Lahov, E., and W. Regelson. 1996. Antibacterial and immunostimulating casein-derived substances from milk: Casecidin, isracidin peptides. Food Chem. Toxicol. 34:131-145. https://doi.org/10.1016/ 0278-6915(95)00097-6.

Li, W., M. Wei, J. Wu, X. Rui, and M. Dong. 2016. Novel fermented chickpea milk with enhanced level of $\gamma$-aminobutyric acid and neuroprotective effect on PC12 cells. PeerJ 4:e2292. https://doi.org/ 10.7717 / peerj.2292.

Lim, H. S., I.-T. Cha, S. W. Roh, H.-H. Shin, and M.-J. Seo. 2017. Enhanced production of gamma-aminobutyric acid by optimizing culture conditions of Lactobacillus brevis HYE1 isolated from kimchi, a Korean fermented food. J. Microbiol. Biotechnol. 27:450-459. https://doi.org/10.4014/jmb.1610.10008.

Manguy, J., P. Jehl, E. T. Dillon, N. E. Davey, D. C. Shields, and T. A. Holton. 2017. Peptigram: A web-based application for peptidomics data visualization. J. Proteome Res. 16:712-719. https://doi.org/ 10.1021/acs.jproteome.6b00751.

Miclo, L., E. Roux, M. Genay, E. Brusseaux, C. Poirson, N. Jameh, C. Perrin, and A. Dary. 2012. Variability of hydrolysis of $\beta-, \alpha_{\mathrm{S1}^{-}}$, and $\alpha_{\mathrm{S} 2}$-caseins by 10 strains of Streptococcus thermophilus and resulting bioactive peptides. J. Agric. Food Chem. 60:554-565. https:// doi.org/10.1021/jf202176d.

Padmanabhan, A., Y. Tong, Q. Wu, J. Zhang, and N. P. Shah. 2018. Transcriptomic insights into the growth phase- and sugar-associated changes in the exopolysaccharide production of a high EPS-producing Streptococcus thermophilus ASCC 1275. Front. Microbiol. 9:1919. https://doi.org/10.3389/fmicb.2018.01919.

Pihlanto, A. 2006. Antioxidative peptides derived from milk proteins. Int. Dairy J. 16:1306-1314. https://doi.org/10.1016/j.idairyj.2006 .06 .005

Power, O., P. Jakeman, and R. FitzGerald. 2013. Antioxidative peptides: Enzymatic production, in vitro and in vivo antioxidant activity and potential applications of milk-derived antioxidative peptides. Amino Acids 44:797-820. https://doi.org/10.1007/s00726 -012-1393-9.

Purwandari, U., N. Shah, and T. Vasiljevic. 2007. Effects of exopolysaccharide-producing strains of Streptococcus thermophilus on technological and rheological properties of set-type yoghurt. Int. Dairy J. 17:1344-1352. https://doi.org/10.1016/j.idairyj.2007.01 .018 .

Rai, A. K., S. Sanjukta, and K. Jeyaram. 2017. Production of angiotensin I converting enzyme inhibitory (ACE-I) peptides dur- ing milk fermentation and their role in reducing hypertension. Crit. Rev. Food Sci. Nutr. 57:2789-2800. https://doi.org/10.1080/ 10408398.2015.1068736.

Sadat-Mekmene, L., J. Jardin, C. Corre, D. Mollé, R. Richoux, M.-M. Delage, S. Lortal, and V. Gagnaire. 2011. Simultaneous presence of $\mathrm{PrtH}$ and PrtH2 proteinases in Lactobacillus helveticus strains improves breakdown of the pure $\alpha_{\mathrm{S1}}$-casein. Appl. Environ. Microbiol. 77:179-186. https://doi.org/10.1128/AEM.01466-10.

Shan, Y., C. X. Man, X. Han, L. Li, Y. Guo, Y. Deng, T. Li, L. W. Zhang, and Y. J. Jiang. 2015. Evaluation of improved $\gamma$-aminobutyric acid production in yogurt using Lactobacillus plantarum NDC75017. J. Dairy Sci. 98:2138-2149. https://doi.org/10 $.3168 /$ jds.2014-8698.

Shimada, M., T. Hasegawa, C. Nishimura, H. Kan, T. Kanno, T. Nakamura, and T. Matsubayashi. 2009. Anti-hypertensive effect of gamma-aminobutyric acid (GABA)-rich Chlorella on high-normal blood pressure and borderline hypertension in placebo-controlled double blind study. Clin. Exp. Hypertens. 31:342-354. https://doi .org/10.1080/10641960902977908.

Song, H. Y., and R. C. Yu. 2018. Optimization of culture conditions for gamma-aminobutyric acid production in fermented adzuki bean milk. J. Food Drug Anal. 26:74-81. https://doi.org/10.1016/ j.jfda.2016.11.024.

Sun, T., S. Zhao, H. Wang, C. Cai, Y. Chen, and H. Zhang. 2009 ACE-inhibitory activity and gamma-aminobutyric acid content of fermented skim milk by Lactobacillus helveticus isolated from Xinjiang koumiss in China. Eur. Food Res. Technol. 228:607-612. https://doi.org/10.1007/s00217-008-0969-9.

Wu, Q., Y.-S. Law, and N. P. Shah. 2015. Dairy Streptococcus thermophilus improves cell viability of Lactobacillus brevis NPSQW-145 and its $\gamma$-aminobutyric acid biosynthesis ability in milk. Sci. Rep. 5:12885. https://doi.org/10.1038/srep12885.

Wu, Q., and N. P. Shah. 2015. Gas release-based prescreening combined with reversed-phase HPLC quantitation for efficient selection of high- $\gamma$-aminobutyric acid (GABA)-producing lactic acid bacteria. J. Dairy Sci. 98:790-797. https://doi.org/10.3168/jds .2014-8808.

Wu, Q., and N. P. Shah. 2017. High $\gamma$-aminobutyric acid production from lactic acid bacteria: emphasis on Lactobacillus brevis as a functional dairy starter. Crit. Rev. Food Sci. Nutr. 57:3661-3672. https://doi.org/10.1080/10408398.2016.1147418.

Wu, Q., H. M. Tun, Y. S. Law, E. Khafipour, and N. P. Shah. 2017. Common distribution of gad operon in Lactobacillus brevis and its GadA contributes to efficient GABA synthesis toward cytosolic near-neutral pH. Front. Microbiol. 8:206. https://doi.org/10.3389/ fmicb.2017.00206

Xiao, T., A. Yan, J.-D. Huang, E. M. Jorgensen, and N. P. Shah. 2020. Comparative peptidomic and metatranscriptomic analyses reveal improved gamma-amino butyric acid production machinery in Levilactobacillus brevis strain NPS-QW 145 cocultured with Streptococcus thermophilus strain ASCC1275 during milk fermentation. Appl. Environ. Microbiol. 87:e01985-e01920. https://doi .org/10.1128/AEM.01985-20.

\section{ORCIDS}

Tingting Xiao @ https://orcid.org/0000-0003-1515-4232

Nagendra P. Shah () https://orcid.org/0000-0003-4746-3232 